\title{
Correction to: Conceptualization and preliminary study of engineering disturbed rock dynamics
}

\author{
Heping Xie $\cdot$ Jianbo Zhu $\cdot$ Tao Zhou $\cdot$ Kai Zhang $\cdot$ Changtai Zhou
}

Published online: 4 August 2020

(C) The Author(s) 2020

Correction to: Geomech. Geophys. Geo-energ. Geo-resour. (2020) 6:34

https://doi.org/10.1007/s40948-020-00157-x

The article Conceptualization and preliminary study of engineering disturbed rock dynamics, written by Heping Xie, Jianbo Zhu, Tao Zhou, Kai Zhang, Changtai Zhou was originally published electronically on the publisher's internet portal on 24 March 2020 without open access. With the author(s)' decision to opt for Open Choice the copyright of the article changed on August 062020 to (C) The Author(s) 2020

The original article can be found online at https:// doi.org/10.1007/s40948-020-00157-x.

H. Xie · J. Zhu ( $\) \cdot$ T. Zhou · K. Zhang · C. Zhou Guangdong Provincial Key Laboratory of Deep Earth Sciences and Geothermal Energy Exploitation and Utilization, Institute of Deep Earth Sciences and Green Energy, College of Civil and Transportation Engineering, Shenzhen University, Shenzhen, China e-mail: jbzhu@tju.edu.cn

URL: http://jgxy.tju.edu.cn/teachers.asp?id=256

H. Xie $\cdot$ T. Zhou $\cdot$ K. Zhang · C. Zhou

Shenzhen Key Laboratory of Deep Underground Engineering Sciences and Green Energy, Shenzhen University, Shenzhen, China

J. Zhu

State Key Laboratory of Hydraulic Engineering Simulation and Safety, School of Civil Engineering, Tianjin University, Tianjin, China and the article is forthwith distributed under a Creative Commons Attribution 4.0 International License (https://creativecommons.org/licenses/by/4.0/), which permits use, sharing, adaptation, distribution and reproduction in any medium or format, as long as you give appropriate credit to the original author(s) and the source, provide a link to the Creative Commons licence, and indicate if changes were made. The original article has been corrected.

Open Access This article is licensed under a Creative Commons Attribution 4.0 International License, which permits use, sharing, adaptation, distribution and reproduction in any medium or format, as long as you give appropriate credit to the original author(s) and the source, provide a link to the Creative Commons licence, and indicate if changes were made. The images or other third party material in this article are included in the article's Creative Commons licence, unless indicated otherwise in a credit line to the material. If material is not included in the article's Creative Commons licence and your intended use is not permitted by statutory regulation or exceeds the permitted use, you will need to obtain permission directly from the copyright holder. To view a copy of this licence, visit http://creativecommons.org/licenses/by/4.0/.

Publisher's Note Springer Nature remains neutral with regard to jurisdictional claims in published maps and institutional affiliations. 